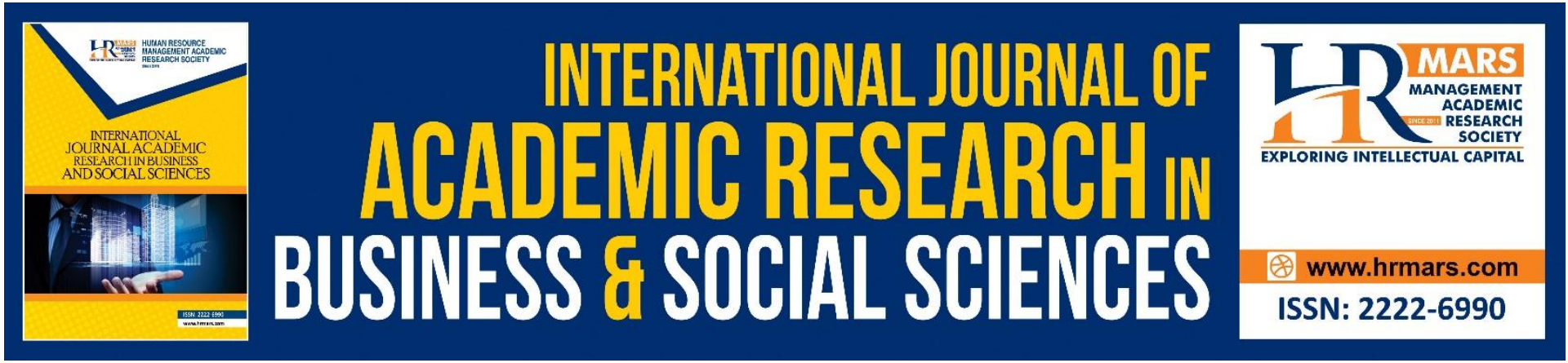

\title{
A Systematic Literature Review on the Influential Family Factors and Cultural Differences in Parent-Adolescent Conflict among Adolescents
}

Khandaker Tasmina Tanni, Zaida Nor Zainudin, Siti Aishah Hassan, Yusni Mohamad Yusop

To Link this Article: http://dx.doi.org/10.6007/IJARBSS/v11-i5/9242

DOI:10.6007/IJARBSS/v11-i5/9242

Received: 17 March 2021, Revised: 20 April 2021, Accepted: 06 May 2021

Published Online: 22 May 2021

In-Text Citation: (Tanni et al., 2021)

To Cite this Article: Tanni, K. T., Zainudin, Z. N., Hassan, S. A., \& Yusop, Y. M. (2021). A Systematic Literature Review on the Influential Family Factors and Cultural Differences in Parent-Adolescent Conflict among Adolescents. International Journal of Academic Research in Business and Social Sciences, 11(5), 405-426.

Copyright: @ 2021 The Author(s)

Published by Human Resource Management Academic Research Society (www.hrmars.com)

This article is published under the Creative Commons Attribution (CC BY 4.0) license. Anyone may reproduce, distribute, translate and create derivative works of this article (for both commercial and non-commercial purposes), subject to full attribution to the original publication and authors. The full terms of this license may be seen at: http://creativecommons.org/licences/by/4.0/legalcode

Vol. 11, No. 5, 2021, Pg. 405 - 426

Full Terms \& Conditions of access and use can be found at http://hrmars.com/index.php/pages/detail/publication-ethics 


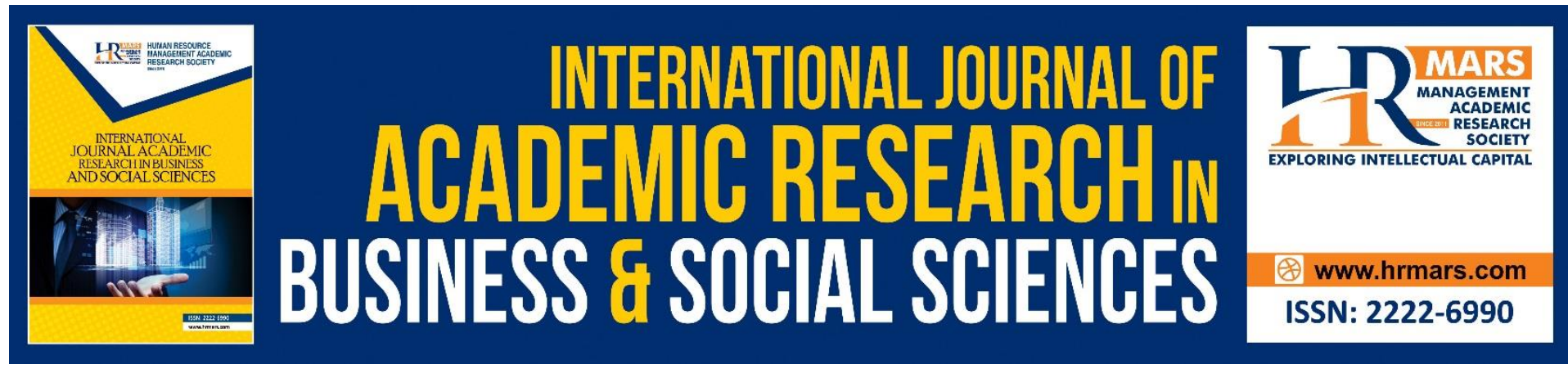

\title{
A Systematic Literature Review on the Influential Family Factors and Cultural Differences in Parent- Adolescent Conflict among Adolescents
}

\author{
Khandaker Tasmina Tanni, Zaida Nor Zainudin, Siti Aishah \\ Hassan, Yusni Mohamad Yusop \\ Faculty of Educational Studies, Universiti Putra Malaysia, Malaysia \\ Email: gs51326@student.upm.edu.my,zaidanor@upm.edu.my, \\ sitiaishahh@upm.edu.my, yusni_my@upm.edu.my
}

\begin{abstract}
Parent-Adolescent conflicts are associated with internalization and externalization problems, school maladjustment, and risky behavior of adolescents. Various studies have shown that the parent-child conflict is a risk factor for depression, anxiety, and low self-esteem among adolescents. The depression levels of adolescents living in families with high levels of conflict have been shown to be higher than those of adolescents who have a healthy relationship with the family. Hence, the purpose of this study was to identify the influential factors of parentadolescent conflict in different cultures around the world and cultural differences within the context of parent-adolescent conflict. The methodology applied inclusion and exclusion criteria based on the Scopus database. A total of 18 articles were selected through the process. The findings of this review discuss the influential factors and cultural difference of parent-adolescent conflict in different countries and also explain the gaps and limitations in the literature assessing influential family factors of parent-adolescent conflict in different countries and different cultures around the world. The findings of this review are beneficial for psychotherapists and professional mental health support providers who work with families and adolescents where the therapists can design the needed plans of counseling for the clients by considering the importance of developing awareness among the parents and adolescents regarding their contribution to building a healthy relationship.
\end{abstract}

Keywords: Parent-adolescent Conflict, Cultural Differences, Influential Factors.

\section{Introduction}

Adolescence always has a disagreement with their parents on daily problems, such as house rules, schoolwork, privileges, family, and social values (Smetana, 2011; Turliuc \& Marici, 2013). These assertions reflect the efforts of the adolescent to achieve freedom, while parents may also consider them as threatening their authority (Rote \& Smetana, 2016; Skinner \& McHale, 2016). If such a struggle becomes serious, it can have a detrimental impact on the well-being and growth of the adolescent as well as the family's atmosphere (Boudreault-Bouchard et al., 2013; Wang et al., 2011). In addition, behavioral concerns, such as drug abuse, truancy, antisocial behaviour, and delinquency can also occur (Hoeve et al., 
2011). Along with a low conflict, high degrees of parental encouragement and fantastic emotions predict the social-emotional functioning (Liew et al., 2014; Piko \& Balázs, 2012) and well-being (Hazel et al., 2014; Larsson et al., 2015) of adolescents. In addition, close and warm relationships with parents support the emotional freedom, autonomy, and identity development of the adolescent (Inguglia et al., 2015). Efforts should also be made to minimize parent-child conflicts for the welfare of the family and the community.

In the field of research on adolescents, parent-adolescent conflict is a common phenomenon. Young people are encouraged to increase more autonomy throughout adolescence than it was during the childhood (e.g., Branje et al., 2012). Parents want to gradually initiate part of their authority for young people to grow to be trained in adult roles and allow the parent-adolescent relationship to shift seriously in the direction of a greater equitable one (Branje et al., 2012). Adolescents typically demand an objective decisionmaking in advance because parents are inclined to provide it (Deković et al., 1997), and this may also create a fertile ground for disputes between parents and adolescents (Collins \& Laursen, 1992). Additionally, adolescence typically coincides with the midlife of parents, a frequently demanding stage of lifestyles, marked by a need to reconsider their life path, control new working conditions, and redefine pride in lifestyles (Van Aken et al., 2006).

The literature has shown that more and more frequent and intensive adolescentparent conflicts are associated with negative youth outcomes (e.g., internalization and externalization problems, school maladjustment, risky behavior) (Buehler, \& Gerard, 2002; Tucker et al., 2003), moreover parental conducts and disputes between parents and young adolescents in particular, are linked to problematic behaviours and child psychological health (Barber, Olsen, \& Shagle, 1994; Collins, \& Lauren, 1992). Parent-child conflicts are most influential during adolescence than other periods of life span (Phinney et al., 2000). Several researchers, including recent psychoanalysts and social-cognitive-psychologists, conclude that rising autonomy during adolescence leads to a reduction of parental proximity and also to an increase in parental-adolescent conflict (Collins, 2004). The key cause of the conflict between parents and adolescents during this period is to demonstrate the challenging attitude towards self-reliance and different expectations of the time frame for autonomy (Smetana, 1989). Destructive conflicts between parents tend to be associated with a deterioration of parent-adolescent relationships and an improvement in parent-adolescent relationship quality (McCoy et al., 2009).

Various studies have shown that parent-child conflict is a risk factor for depression, anxiety, and low self-esteem. Depression levels of adolescents living in families with high levels of conflict have been shown to be higher than adolescents with low levels of conflict and high levels of family unity (Aseltine et al., 1994). The negative relationship of parents and adolescents were found to be associated with the depression of adolescents in studies conducted in Turkey (Demir et al., 2011). Many longitudinal studies have found, however, that the average level of conflict between the ages of 11 and 15 reported by the youth has risen from 11 to 19 years of age (De Goede et al., 2009; McGue et al., 2005) and to 16-19 years of age (De Gede et al., 2009). The two studies also show gender differences, with girls increasing more than boys in the intensity of their parent-adolescent conflicts (De Goede et al., 2009; McGue et al., 2005). A study on the development of adolescent-reported conflict intensity between ages 14 and 17 also reveals heterogeneity in development, with a stable low negativity for most adolescents, and an increasing negativity for a minority of adolescents (Seiffge-Krenke et al., 2010). To conclude, some empirical studies on the trajectories of conflict intensity show an increase, and some show stability. This inconsistency might be due 
to the different age periods examined in the various studies. In all cultures, adolescents pursue the developmental task to achieve autonomy (i.e., volitional agency), while maintaining relatedness (i.e., connectedness to others) with their parents and any other people.

Two important elements, which are the shared activity (cultural practice) and the common sense (cultural interpretation), are viewed on culture as a "socially interactive construction process" (Greenfield, Fuligni, \& Maynard, 2003, p. 462), and the researchers highlight the fact that the relative importance of autonomy versus relationship is culturally distinct, as it relies on the values that are more important. Autonomy is the basis of individualism and the self, while connectivism is the basis of collectivism and interdependent self (Rothbaum \& Trommsdorff, 2007). There are a few studies comparing cultural factors in relation to connections and differences with parents among Estonian, German, and Russian adolescents. In recent decades, in the previous century, the three countries share an extensive history of political, policy, and economic change. These three countries concurrently offer different cultural guidelines. The numbers are relatively high in Germany and Estonia, while Russia is low in individuality (Hofstede 2001). This suggests that people could be more interested in their own needs in Estonia and Germany, while in Russia people prioritize the group's needs (Hofstede, 2001).

The autonomy is respected more than the relationship between the Estonian and German mothers, but less in the relationship between German and Estonian mothers (Töugu et al., 2011). There is a possibility that interpretations of many different issues may vary between cultures (Smetana et al., 2014). In cultures with a higher degree of parental autonomy, young people are permitted to decide independently beforehand (Greenfield et al., 2003). Rothbaum and Trommsdorff (2007) point out that children are given a greater freedom in western cultures to decide, which tasks to carry out or to stop carrying out. In cultures that emphasise on collectivistic values, tasks are often group-oriented and noncompliant by children is considered to be moral violations (Greenfield et al., 2003; Rothbaum \& Trommsdorff, 2007). However, it is likely that the expressions of autonomy and connection are culturally different, in addition to the varying importance. Taking into consideration the discussion of two different forms of connection in 2007 between Rothbaum and Trommsdorff, it could be the relationship that is primarily defined in terms of confidence, in Estonia and Germany, with faith and hope in others. The emphasis is on confidence and trust in others in these and other Western cultures. The other way of connecting is certainty.

One of the previous studies explains that parents-adolescent conflict increases and reaches its peaks during the early years of adolescence and is linked to the time of puberty (Holmbeck \& Hill, 1991). Several studies have found increased levels of conflict in grades six and/or seven, the transitional years between later childhood and adolescence, to be most prevalent in middle school years (Galambos, \& Almeida, 1992; Smetana \& Asquith, 1994). Furthermore, a conflict between adolescents and their mothers, and especially between mothers and daughters occurs more frequently within families (Paikoff \& Brooks-Gunn, 1991). To our knowledge, no systematic review has investigated the cultural variance of parent-adolescent conflict and explored the family factor behind the parent-adolescent conflict. The current review conceptualizes the family factor responsible to increase parentadolescent conflict and cultural variance of parent adolescent-conflict. 


\section{Objectives}

The major purpose of this review was to find out the influential factors responsible for the parent-adolescent conflict and the consequences of this conflict among adolescents. The aim of the current review were to:

1. Identify the influential factors of parent-adolescent conflict in different cultures around the world.

2. Identify the cultural differences belong in different culture on parent-adolescent conflict.

3. Identify the gaps and limitations in the literature assessing family influence and cultural variance in parent-adolescent conflict.

\section{Methodology}

An extensive search of the literature review was conducted in order to identify the nature and predominating factors of the parent-adolescent conflict. The SCOPUS journals were searched to find the scholarly articles. The search criteria were limited to studies that were published between the time period of 2014-2019 in order to get the latest research and findings in discussing the factors and consequences of the parent-adolescent conflict in different cultures. The overall major focus was on the concept of parent-adolescent conflict.

\section{The Search Strategy}

In this literature review, the finalized articles were selected from the journal of early adolescence, journal of adolescent research, journal of child and family studies, journal of research on adolescence, and journal of psychology databases. Firstly, the keyword "parentadolescent conflict" was used to start the search process. Secondly, the search process was characterized by the field of psychology and social sciences. Thirdly, some inclusion and exclusion criteria were scrutinized to acquire the most relevant articles. Finally, the studies of different countries regarding parent-adolescent conflict were selected in order to find out the cultural influences on parent-adolescent conflict.

At the beginning of the search process, 481 articles were found by encoding the keywords. Then, the reviewer searched the articles by setting the limit of research publications, which is from 2014 to 2019 and found 99 articles. For the selected area, 54 articles were selected. By following the inclusion and exclusion criteria, the reviewer finally found 18 journals, which are most relevant to fulfill the purpose of this literature review. The finalized 18 articles were viewed and analyzed thoroughly to reach the goal of this review study by maintaining the objectives of this literature review. 
INTERNATIONAL JOURNAL OF ACADEMIC RESEARCH IN BUSINESS AND SOCIAL SCIENCES Vol. 11, No. 5, 2021, E-ISSN: 2222-6990 @ 2021 HRMARS

Table 1. The Inclusion Criteria

\begin{tabular}{lll}
\hline Inclusion criteria & Particulars & Identified \\
\hline Key term & Parent-adolescent conflict & 481 \\
Year & $2014-2019$ & 99 \\
Selected area & Social Science & 54 \\
& Psvchologv & 18 \\
Country & U.S.A & \\
& Hong Kong & \\
& China & \\
& India & \\
& Mexico & \\
\hline
\end{tabular}




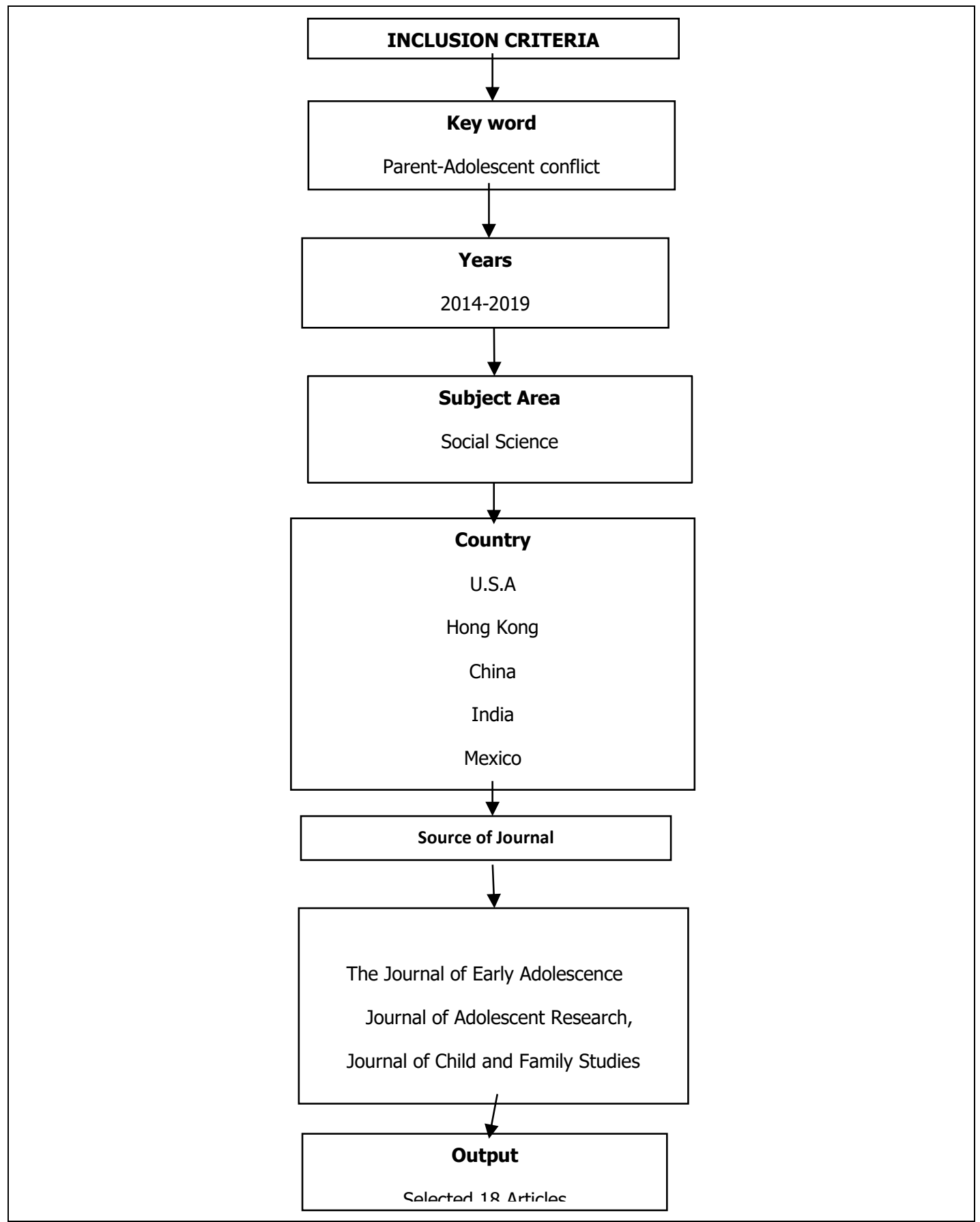

Figure 1. Flow chart of systematic review

\section{Findings and Discussions}

The summary report of the selected articles is presented in Table 2. The findings of the review are presented following the sequences, such as the name of the authors, publication years, journal titles, country, a sample of study and the findings that are in alignment with the purpose of this paper. 
Table 2. Summary of selected literature

\begin{tabular}{|c|c|c|c|c|}
\hline Author (year) & $\begin{array}{l}\text { Title of the } \\
\text { Articles }\end{array}$ & Country & Sample & Findings \\
\hline $\begin{array}{l}\text { Delgado, M. Y., } \\
\text { Nair, R. L., } \\
\text { Updegraff, K. A., \& } \\
\text { Umaña-Taylor, A. } \\
\text { J. } \\
\text { (2019) }\end{array}$ & $\begin{array}{l}\text { Discrimination, } \\
\text { Parent- } \\
\text { Adolescent } \\
\text { Conflict, and Peer } \\
\text { Intimacy: } \\
\text { Examining Risk } \\
\text { and Resilience in } \\
\text { Mexican-Origin } \\
\text { Youths' } \\
\text { Adjustment } \\
\text { Trajectories }\end{array}$ & USA & $\begin{array}{l}46 \\
\text { adolescents }\end{array}$ & 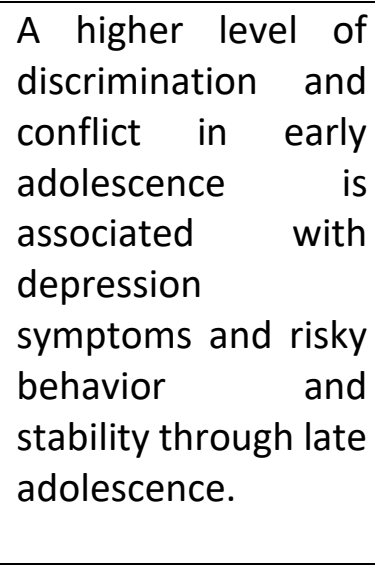 \\
\hline $\begin{array}{l}\text { Liu, L., Wang, N., } \\
\text { \& } \\
\text { Tian, L. (2019) }\end{array}$ & $\begin{array}{l}\text { The Parent- } \\
\text { Adolescent } \\
\text { Relationship and } \\
\text { Risk-Taking } \\
\text { Behaviors Among } \\
\text { Chinese } \\
\text { Adolescents: The } \\
\text { Moderating Role } \\
\text { of Self-Control }\end{array}$ & China & lescents & $\begin{array}{l}\text { The result reveals } \\
\text { that the adolescents } \\
\text { with lower levels of } \\
\text { self-control and } \\
\text { higher level of } \\
\text { parent-adolescent } \\
\text { are significantly } \\
\text { related to the risk- } \\
\text { taking behavior of } \\
\text { adolescents. }\end{array}$ \\
\hline $\begin{array}{l}\text { Mercado, E., Kim, } \\
\text { J., Gonzales, N. A., } \\
\text { \& Fuligni, A. J. } \\
(2019)\end{array}$ & $\begin{array}{l}\text { Emotional Co- } \\
\text { regulation in } \\
\text { Mexican-Origin } \\
\text { Parent- } \\
\text { Adolescent } \\
\text { Dyads: } \\
\text { Associations with } \\
\text { Adolescent } \\
\text { Mental Health }\end{array}$ & & 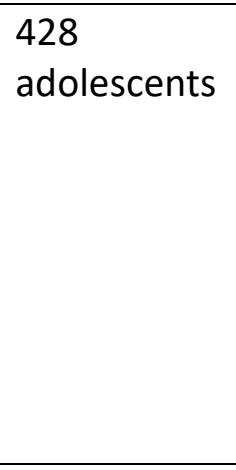 & $\begin{array}{l}\text { Parent-adolescent } \\
\text { interpersonal } \\
\text { relationship has an } \\
\text { influential effect on } \\
\text { the mental health } \\
\text { wellbeing of late } \\
\text { adolescence. }\end{array}$ \\
\hline $\begin{array}{l}\text { Mastrotheodoros, } \\
\text { S., } \\
\text { Van der Graaff, J., } \\
\text { Deković, M., } \\
\text { Meeus, W. H., \& } \\
\text { Branje, S. (2019) }\end{array}$ & $\begin{array}{l}\text { Parent- } \\
\text { Adolescent } \\
\text { Conflict across } \\
\text { Adolescence: } \\
\text { Trajectories of } \\
\text { Informant } \\
\text { Discrepancies and } \\
\text { Associations with } \\
\text { Personality Types } \\
\end{array}$ & 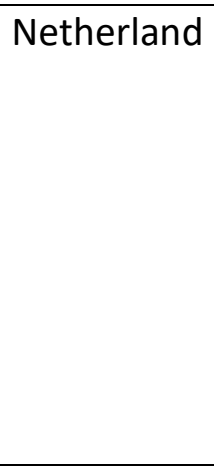 & $\begin{array}{l}497 \\
\text { adolescents }\end{array}$ & $\begin{array}{l}\text { Under controlling } \\
\text { parenthood and } \\
\text { over controlling } \\
\text { adolescent are } \\
\text { highly correlated } \\
\text { with parent- } \\
\text { adolescent } \\
\text { discrepancies. }\end{array}$ \\
\hline $\begin{array}{l}\text { Hou, Y., Kim, S. Y., } \\
\text { \& } \\
\text { Benner, A. D. } \\
(2018)\end{array}$ & $\begin{array}{l}\text { Parent- } \\
\text { Adolescent } \\
\text { Discrepancies in } \\
\text { Reports of } \\
\text { Parenting and }\end{array}$ & Mexico & $\begin{array}{l}604 \\
\text { adolescents }\end{array}$ & $\begin{array}{lr}\text { Adolescents' } & \text { more } \\
\text { negative } & \\
\text { perceptions } & \text { toward } \\
\text { parents } & \text { are } \\
\text { associated } & \text { with }\end{array}$ \\
\hline
\end{tabular}




\begin{tabular}{|c|c|c|c|c|}
\hline & $\begin{array}{l}\text { Adolescent } \\
\text { Outcomes in } \\
\text { Mexican } \\
\text { Immigrant } \\
\text { Families }\end{array}$ & & & $\begin{array}{l}\text { more negative } \\
\text { adolescent } \\
\text { outcomes, whereas } \\
\text { adolescents' more } \\
\text { positive perceptions } \\
\text { relative to parents } \\
\text { are related to more } \\
\text { positive adolescent } \\
\text { outcomes. }\end{array}$ \\
\hline $\begin{array}{l}\text { Buist, K. L., } \\
\text { Verhoeven, M., } \\
\text { Hoksbergen, R., } \\
\text { ter Laak, J., } \\
\text { Watve, S., \& } \\
\text { Paranjpe, } \\
\text { (2017) }\end{array}$ & $\begin{array}{l}\text { Associations of } \\
\text { Perceived } \\
\text { Sibling and } \\
\text { Parent-Child } \\
\text { Relationship } \\
\text { Quality } \\
\text { With Internalizing } \\
\text { and } \\
\text { Externalizing } \\
\text { Problems: } \\
\text { Comparing Indian } \\
\text { and } \\
\text { Dutch Early } \\
\text { Adolescents }\end{array}$ & $\begin{array}{l}\text { Netherland } \\
\text { India }\end{array}$ & $\begin{array}{l}274 \text { Dutch } \\
236 \text { Indian }\end{array}$ & $\begin{array}{l}\text { Cultural difference } \\
\text { exists in the quality } \\
\text { of sibling and } \\
\text { parent-child } \\
\text { relationships. }\end{array}$ \\
\hline $\begin{array}{l}\text { Tamm, A., } \\
\text { Kasearu, K., } \\
\text { Tulviste, T., } \\
\text { Trommsdorff, G., } \\
\text { \& } \\
\text { Saralieva, Z. K. M. } \\
\text { (2017) }\end{array}$ & $\begin{array}{l}\text { Helping Parents } \\
\text { With } \\
\text { Chores or Going } \\
\text { Out with Friends: } \\
\text { Cultural } \\
\text { Differences in } \\
\text { Adolescents' } \\
\text { Responses } \\
\text { to Potentially } \\
\text { Conflicting } \\
\text { Expectations of } \\
\text { Parents } \\
\text { and Peers }\end{array}$ & $\begin{array}{l}\text { Europe } \\
\text { (Estonian, } \\
\text { German and } \\
\text { Russian) }\end{array}$ & $\begin{array}{l}894 \\
\text { adolescents }\end{array}$ & $\begin{array}{l}\text { The values } \\
\text { developed from } \\
\text { different culture } \\
\text { have an influence on } \\
\text { parent-child } \\
\text { disagreement. }\end{array}$ \\
\hline $\begin{array}{l}\text { Eadeh et al. } \\
(2017)\end{array}$ & $\begin{array}{l}\text { Longitudinal } \\
\text { Evaluation of the } \\
\text { Role of Academic } \\
\text { and Social } \\
\text { Impairment and } \\
\text { Parent- } \\
\text { Adolescent } \\
\text { Conflict in the } \\
\text { Development of } \\
\text { Depression in }\end{array}$ & USA & $\begin{array}{l}336 \\
\text { adolescents }\end{array}$ & $\begin{array}{l}\text { This study explains } \\
\text { that parent- } \\
\text { adolescent conflict } \\
\text { influence develops } \\
\text { social impairment } \\
\text { and depression. }\end{array}$ \\
\hline
\end{tabular}


Adolescents with

ADHD

\begin{tabular}{|c|c|c|c|c|}
\hline $\begin{array}{l}\text { Weymouth, B. \& } \\
\text { Buehler, C. (2016) }\end{array}$ & $\begin{array}{l}\text { Adolescent and } \\
\text { Parental } \\
\text { Contributions to } \\
\text { Parent- } \\
\text { Adolescent } \\
\text { Hostility Across } \\
\text { Early Adolescence }\end{array}$ & USA & $\begin{array}{l}416 \\
\text { adolescents }\end{array}$ & $\begin{array}{l}\text { Mentions that } \\
\text { higher parental } \\
\text { intrusiveness is } \\
\text { associated with } \\
\text { increased parent- } \\
\text { adolescent hostility. }\end{array}$ \\
\hline $\begin{array}{l}\text { Ehrlich et al. } \\
(2016)\end{array}$ & $\begin{array}{l}\text { When Parents } \\
\text { and Adolescents } \\
\text { Disagree About } \\
\text { Disagreeing: } \\
\text { Observed } \\
\text { Parent- } \\
\text { Adolescent } \\
\text { Communication } \\
\text { Predicts } \\
\text { Informant } \\
\text { Discrepancies } \\
\text { About Conflict }\end{array}$ & USA & $\begin{array}{l}189 \\
\text { adolescents }\end{array}$ & \begin{tabular}{lr}
\multicolumn{3}{l}{ Disagreement } \\
between parents \\
and adolescents \\
regarding \\
conflicting situation \\
is associated with \\
depressive \\
symptoms and \\
discrepancy in \\
reported conflict \\
situations.
\end{tabular} \\
\hline $\begin{array}{l}\text { Padilla et al. } \\
(2016)\end{array}$ & $\begin{array}{l}\text { Parent-Youth } \\
\text { Differences in } \\
\text { Familyism Values } \\
\text { from Adolescence } \\
\text { into Young } \\
\text { Adulthood: } \\
\text { Developmental } \\
\text { Course and Links } \\
\text { with Parent- } \\
\text { Youth Conflict }\end{array}$ & USA & $\begin{array}{l}246 \\
\text { participants }\end{array}$ & $\begin{array}{l}\text { The findings reveal } \\
\text { that higher parent- } \\
\text { youth conflict is } \\
\text { associated with } \\
\text { greater differences } \\
\text { in parent-youth } \\
\text { familyism values and } \\
\text { on the contrary, the } \\
\text { familyism values } \\
\text { does not predict } \\
\text { parent-youth } \\
\text { conflict. }\end{array}$ \\
\hline $\begin{array}{l}\text { Skinner, O. D. \& } \\
\text { McHale, S. M. } \\
(2016)\end{array}$ & $\begin{array}{l}\text { Parent- } \\
\text { Adolescent } \\
\text { Conflict in African } \\
\text { American Families }\end{array}$ & USA & $\begin{array}{l}187 \\
\text { adolescents }\end{array}$ & \begin{tabular}{lr}
\multicolumn{2}{l}{ Findings show that } \\
family conflict has a \\
relationship with \\
depressive \\
symptoms, risky \\
behavior, \\
$\begin{array}{l}\text { acceptance } \\
\text { parents, } \\
\text { acceptance } \\
\text { children. }\end{array}$
\end{tabular} \\
\hline $\begin{array}{l}\text { Moed, A. et al. } \\
\text { (2015) }\end{array}$ & $\begin{array}{l}\text { Parent- } \\
\text { Adolescent }\end{array}$ & USA & $\begin{array}{l}138 \\
\text { adolescents }\end{array}$ & $\begin{array}{l}\text { Reveals that a high } \\
\text { proportion }\end{array}$ \\
\hline
\end{tabular}




\begin{tabular}{|c|c|c|c|c|}
\hline & $\begin{array}{lr}\text { Conflict } & \text { as } \\
\text { Sequences of } \\
\text { Reciprocal } \\
\text { Negative } \\
\text { Emotion: Links } \\
\text { with Conflict } \\
\text { Resolution and } \\
\text { Adolescents' } \\
\text { Behavior } \\
\text { Problems } \\
\end{array}$ & & & $\begin{array}{l}\text { conflicts is } \\
\text { associated with } \\
\text { unresolved and } \\
\text { longer conflicts and } \\
\text { adolescents' } \\
\text { behavior problems. }\end{array}$ \\
\hline $\begin{array}{l}\text { Maciejewski et al. } \\
(2014)\end{array}$ & $\begin{array}{l}\text { The Development } \\
\text { of Adolescent } \\
\text { Generalized } \\
\text { Anxiety and } \\
\text { Depressive } \\
\text { Symptoms in the } \\
\text { Context } \\
\text { Adolescent Mood } \\
\text { Variability and } \\
\text { Parent- } \\
\text { Adolescent } \\
\text { Negative } \\
\text { Interactions }\end{array}$ & 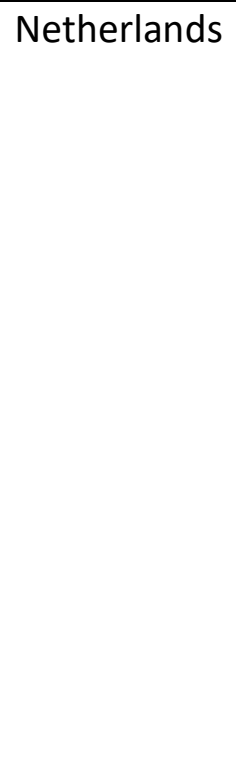 & $\begin{array}{l}456 \\
\text { adolescents }\end{array}$ & $\begin{array}{l}\text { Adolescents mood } \\
\text { variability is linked } \\
\text { with developmental } \\
\text { symptoms of } \\
\text { generalized anxiety } \\
\text { and depression } \\
\text { during the } \\
\text { adolescence period, } \\
\text { but few evidence } \\
\text { found that the } \\
\text { negative interaction } \\
\text { between parent and } \\
\text { adolescent } \\
\text { internalizes problem } \\
\text { development. }\end{array}$ \\
\hline $\begin{array}{l}\text { Leung, J. T. Y. \& } \\
\text { Shek, D. T. L. } \\
(2014)\end{array}$ & $\begin{array}{l}\text { Parent- } \\
\text { Adolescent } \\
\text { Discrepancies in } \\
\text { Perceived } \\
\text { Parenting } \\
\text { Characteristics } \\
\text { and Adolescent } \\
\text { Developmental } \\
\text { Outcomes in Poor } \\
\text { Chinese Families }\end{array}$ & Hong Kong & $\begin{array}{l}275 \\
\text { adolescents }\end{array}$ & $\begin{array}{l}\text { This study reveals } \\
\text { that parent-child } \\
\text { discrepancies in } \\
\text { perceived parental } \\
\text { characteristics have } \\
\text { negative impacts on } \\
\text { the developmental } \\
\text { outcomes of } \\
\text { adolescents. }\end{array}$ \\
\hline $\begin{array}{l}\text { Sorkhabi \& } \\
\text { Middaugh (2014) }\end{array}$ & $\begin{array}{l}\text { How Variations in } \\
\text { Parents Use of } \\
\text { Confronted and } \\
\text { Coercive Control } \\
\text { Relate } \\
\text { Variations in } \\
\text { Parent- } \\
\text { Adolescent } \\
\text { Conflict, } \\
\text { Adolescent } \\
\text { Disclosure, and } \\
\text { Parental }\end{array}$ & USA & $\begin{array}{l}182 \\
\text { adolescents }\end{array}$ & $\begin{array}{l}\text { Examined parental } \\
\text { control, parent- } \\
\text { adolescent conflict } \\
\text { frequency, and } \\
\text { sharing attitude of } \\
\begin{array}{l}\text { adolescents with } \\
\text { parents. }\end{array}\end{array}$ \\
\hline
\end{tabular}




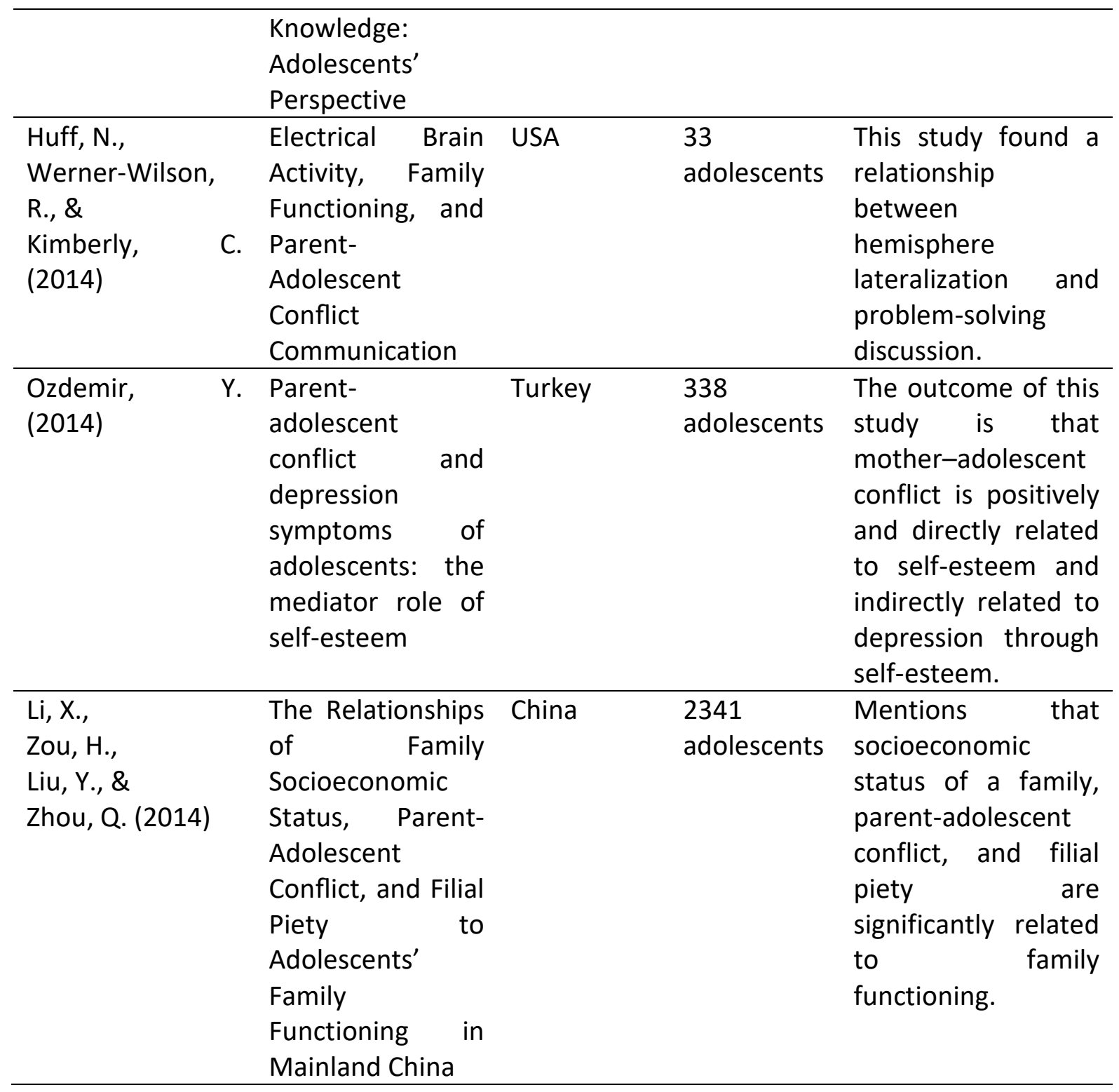

The systematic review was designed to answer three questions. The findings related to each of the questions are summarized as follows.

The influential family factors of parent-adolescent conflict in different countries around the world

As expected, this evaluation recognized a range of household factors throughout a range of cultures that appears to have substantial influences on the parent-adolescent conflict. The influential elements and consequences of parent-adolescent warfare vary from subculture to culture. In every way of life, the core factors at the back of the hostilities are one of a kind, but the penalties were found greater or much less similar, which are associated with intellectual health crisis among adolescents. The generalization of the findings must be done cautiously as the influential family elements are one of a kind in a couple of countries.

In Turkish culture, good evidence was found that conflict with the mother has more impact on the self-esteem of adolescents than that with the father. Children start learning about themselves from their families at the very beginning of childhood. In addition, negative self-perception can develop among children after receiving negative feedback from the family, and the risk factor for depression susceptibility can increase. Further, disputes between parents and adolescents are directly linked to self-esteem, while the degree of 
depression in the Turkish culture is indirectly determined (Ozdemir, 2014). Additionally, clear evidence was found from a Dutch longitudinal research project, which culture is entirely different from the Turkish culture, that the mood variability of adolescents increases an adolescent's generalized anxiety and depression levels. Terrible interactions with parents have not been shown to be related to anxiety and depression. In the adolescence periods, the main developmental aspects of the relationship between parents and children dictate that parents are interactive and productive with their children (Maciejewski et al., 2014).

A portion of the family factors was identified in Hong Kong that the view of guardians and teenagers is diverse with respect to parental responsiveness, parental demandingness, parental control, and generally speaking, parental conduct. Other than that, parent and juvenile errors adversely anticipate young adults' accomplishment, inspiration, and mental capability. Furthermore, this inconsistency negatively affects the accomplishment territory of the young adult (Leung \& Shek, 2014). Be that as it may, the image of family issues in China is distinctive where parents and young adults clash was found as a middle person between equal filial devotion and family working. In subtleties, a complementary dutiful devotion positively affects the working of the family, and a higher equal obedient devotion prompts more beneficial working of the family. Dictator dutiful devotion negatively affects family working rather than equal obedient devotion (Li et al., 2014). Negative family working of Mexican root families were found to be connected with differential paces of assimilation among parents and juveniles, and all the more broadly underpins the possibility of keeping up with the contribution to social qualities from one's nation, which is connected to more certain family connections (Smokowski et al., 2008). More prominent co-regulation of bliss among guardians and adolescents was found to be exceptionally associated with the positive family connections as the outcome of biculturalism.

In any case, the image of family issues in China is diverse where parent-adolescent conflict was found as an arbiter between equal filial devotion and family work. In subtleties, a proportional dutiful devotion positively affects the working of the family, and higher reciprocal filial piety leads to a healthier functioning of the family. An authoritarian filial piety has a negative effect on family functioning as opposed to reciprocal filial piety (Li et al., 2014). Negative family functioning of Mexican origin families was identified to have a correlation with differential rates of acculturation between parent and adolescent (Smokowski et al., 2008). More prominent co-regulation of satisfaction among guardians and adolescents was found to profoundly correspond with the positive family connections as the outcome of biculturalism. An alternative explanation can be made that high levels of conflict between parents and children will create a negative view of the world of children, which easily causes problems to become externalized (Liu, Wang, \& Tian, 2019). In the family, the personality pattern of the family member is closely related to internalizing or externalizing issues. For instance, the lowest levels of conflict intensity and the lowest differences were recorded by resilient adolescents and parents. The bond between parents and adolescents relies on how they view their bond differently. In families, in which adolescents have more internalizing or externalizing issues (Crocetti et al., 2016), or difficulties in their identity development, parentadolescent experiences appear to be worse. The essence of parenting has been described as a family problem that is linked to the dispute between parents and teenagers. For example, in their relationship with their fathers, over-controlled adolescents do not express their negative emotions as freely. Compared to becoming a resilient parent, becoming an undercontrolling parent has a detrimental effect on father-adolescent differences (Mastrotheodoros et al., 2020. 
In the Indian and Dutch societies where the relationship between relatives is a strong predictor to predict the disguise and externalize the problem among young adults, was found to be another family concern. More kin discord, less fatherly assistance, and more negative cooperation in the parent-kid relationship are related to all the more externalizing and disguising problems in the Dutch as well as Indian early youths (Buist et al., 2017). The USA relies on the commitment of guardians and juveniles to establish a strong relationship. This study found that parental nosiness plays a compelling role in establishing an unfriendly link between guardians and juveniles. Furthermore, this study shows that the age range of 14 15 , is particularly pivotal and is a formative window for parental impact on young adults' subsequent guardian associations (Weymouth \& Buehler, 2016). The style of parenting often influences the conflict between parents and adolescents. According to Sorkhabi and Middaugh (2014), an authoritarian parenting is associated with a higher degree of conflict and has a correlation with a certain adolescent maladaptive behavior, such as bullying, ridiculing, challenging, demanding, and threatening without explanation.

Parental experiences of perpetual foreigner stereotype and bicultural management challenge in Asian American can also be viewed as family stressors that can impact adolescents' adaptation through family processes. Consider that during the acculturation phase of ethnic minorities, our research statistically accounted for family socioeconomic factors (i.e., economic stress, parental employment, and parental education level), which typically intertwine with other cultural stressors. For two reasons, this may be especially true for families of Asian American immigrants. First, in Asian communities, there is a traditional focus on family values and connectedness. Second, the youth of these families may go through growing exploration of ethnic identity during these developmental periods, and therefore, may need a sense of link with parents, who are the primary agents of ethnic socialization (Kim, Hou, \& Wang, 2016).

A biopsychosocial research was reviewed to investigate the parent-adolescent conflict dynamics to see the parent-adolescent relationship by considering an electrical brain activity using the electroencephalography technology and the study explains that during parentadolescent problem-solving conversations, hemisphere lateralization occurs (Huff et al., 2014). Parent-adolescent differences may provide valuable family process knowledge that is helpful in predicting adolescents' outcomes. In addition, researchers and practitioners should consider all dyads to obtain a more thorough understanding of parenting discrepancies, given that father- and mother-adolescent discrepancies show different trends and consequences for adolescents' well-being (Hou, Kim, \& Benner, 2018). Moed et al. (2015) define and clarify the trend of parent-adolescent conflict, stating that parent-adolescent conflict has affected the conflict resolution process and is linked to an adolescent's disruptive actions. Negative emotions may assess the strength of the adolescent's crisis to overcome the parentadolescent conflict.

Finally, the relationship between internal family issues and parent-adolescent conflict appears to create different pathways to explain the influence of family factors on parentadolescent conflict. Further research could address the influence of socioeconomic status on parent-adolescent conflict in other minority groups.

\section{The cultural difference in different cultures regarding parent-adolescent conflict}

A variety of reasons have been found that the representations of parent-adolescent conflict vary across different societies, such as in the USA and Netherlands, and the higher conflict has been closely associated with the risk factor of depression and other mental health 
disorders. On the contrary, adolescents in Hong Kong view the parental attitude of fathers and mothers in different ways, while no other countries published similar results. Parentyouth differences have been found as an indicator of family values in Mexican American families, but no evidence has been found as to whether or not family values can predict the conflict area. An association was discovered between generational status and happiness coregulation, but not with anxiety. The highest correlation in everyday happiness is displayed by adolescents born in the U.S. with a parent born in Mexico, a trend that is statistically distinct from adolescents who were born in Mexico (i.e., first generation) but not distinct relative to families in the United States (i.e., third generation) where both young people and parents were born in. According to the model of acculturation gap-distress, discrepancies in rates at which parents and children adapt to a host country's culture can have a negative effect on family functioning and adjustment of youth by exacerbating current intergenerational stress. There is a greater co-regulation of everyday happiness in Mexican families who reported increased cooperation (i.e., getting along) and consisted of caregivers who immigrated from Mexico and had children born in the U.S. In late adolescence, young people who reported higher levels of internalizing symptoms displayed greater co-regulation of daily distress with their caregiver (Mercado et al., 2019).

On the other hand, adolescents of any Turkish family are self-oriented in their families and this orientation influences the adolescents' self-perception and as a result, the risk of depression rises. The dispute between parents and teenagers also leads to the family's operations in China. In our samples of both father-child and mother-child negative relationships, major variations were found. Young Indians registered more negative experiences than young Dutch. In particular, the early Indian and Dutch adolescents vary in their warmth towards their siblings. The transformation of the relationship between parents and young people during this period may reflect the intensity and divergence among parents and teenagers (e.g., De Los reyes \& Ohannessian, 2016). In addition, the relationships between parents and young people (Mastrotheodoros et al., 2019) could affect the character types of young people and parents. Parent-adolescent relationships include a lower parental involvement and higher parent-adolescent negative experiences in families that experience more disruptive and less positive interparental disputes than other families. The lower partnership families between parents and teenagers tend to be more damaging interparental conflict mediation techniques.

The analysis reveals other cultural differences in the Dutch and Indian cultures, where the Netherlands has been discovered as a nation with more individualistic characteristics, and India is a country with more collectivist features. In individualistic cultures, individuals are judged without being firmly attached to social relations and the society as an individual with equal and free status. On the other hand, the emphasis is more on interpersonal relationships in collectivist societies; individuals are seen as dependent on the social order (Buist et al., 2017). In more collectivist societies, relationships between parents and children appear to be more hierarchical and less egalitarian compared to individualistic cultures, which may contribute to less warmth. Moreover, in these collectivist societies, the greater focus on conformity is thought to result in lower levels of conflict between parents and their children. There were substantially lower levels of parental warmth for children and adolescents from collectivist cultural groups than for children and adolescents from individualistic cultural groups. A parent-child conflict in collectivist countries has seen far less conflicts than in individualistic culture communities. 
A different pattern of parent-adolescent conflict was observed in Estonian, German, and Russian adolescents with complex relationships and conflicts with their parents. These countries reflect various cultural orientations as well. Germany and Estonia had relatively high levels, while Russia had a low degree of individualism. This indicates that individuals may be more concerned with their own needs in Estonia and Germany, while individuals prioritize the needs of the community in Russia. The autonomous-related model emphasizing both autonomy and relatedness is likely to be advocated by Estonian mothers, while the parenting priorities of German mothers represent a clearer orientation towards autonomy and the ideals of Russian mothers represent a related orientation. Both Estonian and German mothers were found to value autonomy more than connection, but German mothers stress connection less than Estonian mothers (Tõugu et al., 2011). Similarly, parental interference in the USA is strongly connected to a hostile relationship with their children, but no clear findings show that negative experiences are associated with the parent-adolescent conflict in the Netherlands. In some ways, common results from various research have shown that adolescents' negative emotions are associated with a higher parent-adolescent conflict. Moreover, negative feelings are responsible for decreasing the strength of adolescents to cope with this conflict.

Gaps and Limitations are there in the Literature assessing influential family factors of parentadolescent conflict in different countries and cultural difference around the world

In the literature, there are many differences and weaknesses found. In this study, using the systematic review, pathways were evaluated, participants were included, and the measures applied were substantially heterogeneous. However, peer and school influences are not well reflected by the literature, but the individual factors at the individual level are so varied that it is difficult to identify a clear picture. Many countries have not indicated how social status affects adolescents' mental health, so a replication is needed to determine whether these factors are relevant in different subgroups and cultures. This means that it is important to define relationships with parents more specifically in order to figure out the informal interaction between them. No research can analyze all the factors of interest, so it is difficult to decide how these factors interact. It is difficult for a cross-sectional research to provide a proof of causal relationships. The absence of research examining the relationship between parents and adolescents in low- and middle-income countries is one of the most significant gaps in the literature. The outcomes of studies performed in developed countries may not be generalizable to low- and middle-income countries, so it is crucial that future research addresses this substantial gap in the literature. In addition, most research has been conducted in the United States of America and European countries, restricting the generalizability of findings to other contexts.

\section{Implications of the Study}

The findings of this review study can also be used to inform school administrators on the focus of the impact of parent-adolescent conflict that may develop the symptoms of mental health disorder and parental contribution to prevent it. These findings can be interpreted by the school authority and as such they can explore an area of thinking to implement programs that are targeted to assist parents and promote late adolescent's mental health well-being as well as reduce the negative effects of parental conflict behaviors. This systematic review will be beneficial for psychotherapists and professional mental health support providers who work with families and adolescents. Therapists can design their plans 
of counseling needed for the clients by considering cultural influence on the parentadolescent relationship and the importance of developing awareness among the parents and adolescents regarding their contribution to creating a healthy relationship. Besides that, an educational counselor can benefit from this review study in terms of understanding the core difficulties an adolescent may face to achieve a better performance.

The findings from this study will be effective for the Ministry of Education to better understand and realize the influential factors of adolescent and parents, which are the core causes behind the parent-adolescent conflict. The authority can execute a plan to provide a training program, such as anger management, stress management, behavior management, and develop social communication skills for adolescents to improve their social skills and selfunderstanding in creating a healthy relationship with their parents and as for the parents, an awareness program that can help them realize about their contribution in terms of providing a good understanding to their children.

Finally, the findings of this review are beneficial to psychotherapists and professional mental health support providers who work with families and adolescents where the therapist can design the plans of counseling needed for their clients by considering the importance of developing awareness among the parents and adolescents regarding their contribution to creating a healthy relationship.

\section{Conclusion}

Adolescents from different countries and cultural backgrounds have varying experiences with parent-adolescent relationships and behavioral issues. It is important to recognize the driving factors behind the adolescent conflict with parent in designing strategies and approaches to reduce adolescents' adverse behavioral development. An increasing body of research suggests that conflict between parents and adolescents directly influences the potential outcomes of an adolescent. In addition, this conflict can differ from a cultural context to mental health conditions, such as depression, anxiety, and adolescents' maladaptive behaviours. The literature shows that parenthood is closely linked to building self-esteem, which leads to fewer family conflicts. Parents must be mindful of their commitment to building a better relationship with their adolescents, which in turn would boost their selfesteem, self-confidence, and eventually self-performance that can also be of value to parents. From the review, it is clearly stated that the parenting style, parental attitude and behavior, adolescent's perception, and negative emotion and cognition are responsible for creating an unhealthy relationship between parents and adolescents. The characteristic of this study indicates that different countries experience conflict between parents and adolescents in many ways, with similar consequences. Finally, parent-adolescent disputes are affected by parenting style and the perception, emotion, and cognitive awareness of teenagers. In addition, it is closely associated with the negative consequence of puberty.

\section{References}

Aseltine, R. H., Gore, S., \& Colten, M. E. (1994). Depression and the social developmental context of adolescence. Journal of Personality and Social Psychology, 67(2), 252-263.

Barber, B. K., Olsen, J. E., \& Shagle, S. C. (1994). Associations between parental psychological and behavioral control and youth internalized and externalized behaviors. Child Development, 65(4), 1120-1136.

Bilsky, S. A., Friedman, H. P., Karlovich, A., Smith, M., \& Leen-Feldner, E. W. (2020). The interaction between sleep disturbances and anxiety sensitivity in relation to 
adolescent anger responses to parent adolescent conflict. Journal of Adolescence, 84, 69-77.

Boudreault-Bouchard, A. M., Dion, J., Hains, J., Vandermeerschen, J., Laberge, L., \& Perron, M. (2013). Impact of parental emotional support and coercive control on adolescents' self-esteem and psychological distress: Results of a four-year longitudinal study. Journal of Adolescence, 36, 695-704.

Branje, S. J., Van Doorn, M., Van der Valk, I., \& Meeus, W. (2009). Parent-adolescent conflicts, conflict resolution types, and adolescent adjustment. Journal of Applied Developmental Psychology, 30(2), 195-204.

Branje, S. J. T., Keijsers, L. G. M. T., Doorn, Van, M. D., \& Meeus, W. H. J. (2012). Interpersonal and Intrapersonal Processe $s$ in the Development of Adolescent Relationships. In B. Laursen, W. A.Collins, (Eds.), Relationship pathways: From adolescence to young adulthood. Thousand Oaks, CA: Sage Publications.

Branje, S. J. T., Laursen, B., \& Collins, W. A. (2012). The Routledge handbook of family communication. In A. L. Vangelisti (Ed.), The Routledge handbook of family communication. 2nd edn (pp. 271-286). Routledge.

Buehler, C., \& Gerard, J. M. (2002). Marital conflict, ineffective parenting, and children's and adolescents' maladjustment. Journal of Marriage \& Family, 64, 78-92.

Buist, K. L., Verhoeven, M., Hoksbergen, R., ter Laak, J., Watve, S., \& Paranjpe, A. (2017). Associations of perceived sibling and parent-child relationship quality with internalizing and externalizing problems: Comparing Indian and Dutch early adolescents. The Journal of EarlyAdolescence, 37(8), 1163-1190.

Collins, W. A., \& Laursen, B. (2004). Changing Relationships, Changing Youth: Interpersonal Contexts of Adolescent Development. The Journal of Early Adolescence, 24(1), 55-62.

Collins, W. A., \& Laursen, B. (1992). Conflict and the transition to adolescence. In C. U.Shantz, \& W. W. Hartup (Eds.), Conflict in Child and Adolescent Development (pp. 216-241). New York, NY: Cambridge University Press.

Collins, W. A., \& Laursen, B. (1992). Conflict and relationships during adolescence. In C. U. Shantz \& W. W. Hartup (Eds.), Cambridge studies in social and emotional development. Conflict in child and adolescent development (pp. 216-241). New York, NY: Cambridge University Press.

De Goede, I. H. A., Branje, S. J. T., \& Meeus, W. H. J. (2009). Developmental changes in adolescents' perceptions of relationships with their parents. Journal of Youth and Adolescence, 38, 75-88.

Demir, T., Karacetin G., Eralp Demir D., Uysal O. (2011). Epidemiology of depression in an urban population of Turkish children and adolescents. Journal of Affective Disorder, $134,168-176$.

Dekovic, M. (1999) Risk and protective factors in the development of problem behavior during adolescence. Journal of Youth Adolescence, 28, 667-685.

Deković, M., Noom, M. J., \& Meeus, W. (1997). Expectations regarding development during adolescence: Parental and adolescent perceptions. Journal of Youth and Adolescence, 26, 253-272.

Eagly, A. H., \& Wood, W. (1994). Using research syntheses to plan future research. In H. Cooper \& L. V. Hedges (Eds.), The Handbook of Research Synthesis (p. 485-500). Russell Sage Foundation. 
Delgado, M. Y., Nair, R. L., Updegraff, K. A., \& Umaña-Taylor, A. J. (2019). Discrimination, Parent-Adolescent Conflict, and Peer Intimacy: Examining Risk and Resilience in Mexican-Origin Youths' Adjustment Trajectories. Child development, 90(3), 894-910.

Eadeh, H. M., Bourchtein, E., Langberg, J. M., Eddy, L. D., Oddo, L., Molitor, S. J., \& Evans, S. W. (2017). Longitudinal evaluation of the role of academic and social impairment and parent-adolescent conflict in the development of depression in adolescents with ADHD. Journal of child and family studies, 26(9), 2374-2385.

Ehrlich, K. B., Richards, J. M., Lejuez, C. W., \& Cassidy, J. (2016). When parents and adolescents disagree about disagreeing: Observed parent-adolescent communication predicts informant discrepancies about conflict. Journal of Research on Adolescence, 26(3), 380-389.

Galambos, N. L., \& Almeida, D. M. (1992). Does parent-adolescent conflict increase in early adolescence? Journal of Marriage and the Family, 737-747.

Greenfield, P. M., Keller, H., Fuligni, A., \& Maynard, A. (2003). Cultural pathways through universal development. Annual Review of Psychology, 54, 461-490.

Hazel, N. A., Oppenheimer, C. W., Technow, J. R., Young, J. F., \& Hankin, B. L. (2014). Parent relationship quality buffers against the effect of peer stressors on depressive symptoms from middle childhood to adolescence. Developmental Psychology, 50, 2115-2123.

Holmbeck, G. N., \& Hill, J. P. (1991). Conflictive engagement, positive affect, and menarche in families with seventh-grade girls. Child Development, 62(5), 1030-1048.

Hofstede, G. (2001). Culture's Consequences: Comparing Values, Behaviors, Institutions and Organizations Across Nations. Sage publications.

Hoeve, M., Dubas, J. S., Gerris, J. R., van der Laan, P. H., \& Smeenk,W. (2011). Maternal and paternal parenting styles: Unique and combined links to adolescent and early adult delinquency. Journal of Adolescence, 34, 813-827.

Hou, Y., Kim, S. Y., \& Benner, A. D. (2018). Parent-adolescent discrepancies in reports of parenting and adolescent outcomes in Mexican immigrant families. Journal of Youth and Adolescence, 47(2), 430-444.

Huff, N., Werner-Wilson, R., \& Kimberly, C. (2014). Electrical brain activity, family functioning, and parent-adolescent conflict communication. Contemporary Family Therapy, 36(3), 409-416.

Hulsbosch, A. K., Boyer, B. E., \& Van der Oord, S. (2020). Parent-Adolescent Conflict in Adolescents with ADHD: Rater Agreement and Associated Factors. Journal of Child and Family Studies, 29(12), 3447-3458.

Inguglia, C., Ingoglia, S., Liga, F., Lo Coco, A., \& Lo Cricchio, M. G. (2015). Autonomy and relatedness in adolescence and emerging adulthood: Relationships with parental support and psychological distress. Journal of Adult Development, 22, 1-13.

Lamborn, S. D., Mounts, N. S., Steinberg, L., \& Dornbusch, S. M. (1991). Patterns of competence and adjustment among adolescents from authoritative, authoritarian, indulgent, and neglectful families. Child Development, 62(5), 1049-1065.

Larsson, M., Sundler, A. J., Ekebergh, M., \& Björk, M. (2015).Altering the parenting role: Parents' experience of supporting the health and well-being of their adolescent girls. Child and Youth Care Forum, 44, 419-432.

Liew, J., Kwok, O., Chang, Y-P., Chang, B. W., \& Yeh, Y-C. (2014). Parental autonomy support predicts academic achievement through emotion-related self-regulation and adaptive 
skills in Chinese American adolescents. Asian American Journal of Psychology, 5, 214222.

Leung, J. T. Y., \& Shek, D. T. L. (2014). Parent-adolescent discrepancies in perceived parenting characteristics and adolescent developmental outcomes in poor Chinese families. Journal of Child and Family Studies, 23(2), 200-213.

Li, X., Zou, H., Liu, Y., \& Zhou, Q. (2014). The relationships of family socioeconomic status, parent-adolescent conflict, and filial piety to adolescents' family functioning in Mainland China. Journal of Child and Family Studies, 23(1), 29-38.

Liu, L., Wang, N., \& Tian, L. (2019). The parent-adolescent relationship and risk-taking behaviors among Chinese adolescents: The moderating role of self-control. Frontiers in psychology, 10, 542.

McCoy, K. P., Cummings, E. M., \& Davies, P. T. (2009). Constructive and destructive marital conflict, emotional security and children's prosocial behavior. Journal of Child Psychology and Psychiatry, 50(3), 270-279.

Maciejewski, D. F., Van Lier, P. A., Neumann, A., Van der Giessen, D., Branje, S. J., Meeus, W. H., \& Koot, H. M. (2014). The development of adolescent generalized anxiety and depressive symptoms in the context of adolescent mood variability and parentadolescent negative interactions. Journal of Abnormal Child Psychology, 42(4): 515526.

Mastrotheodoros, S., Van der Graaff, J., Deković, M., Meeus, W. H., \& Branje, S. (2020). Parent-adolescent conflict across adolescence: Trajectories of informant discrepancies and associations with personality types. Journal of youth and adolescence, 49(1), 119-135.

McGue, M., Elkins, I., Walden, B., \& lacono, W. G. (2005). Perceptions of the parentadolescent relationship: a longitudinal investigation. Developmental Psychology, 41(6), 971.

Mastrotheodoros, S., Van der Graaff, J., Deković, M., Meeus, W. H., \& Branje, S. (2019). Parent-adolescent conflict across adolescence: Trajectories of informant discrepancies and associations with personality types. Journal of Youth and Adolescence, 1-17.

Mercado, E., Kim, J., Gonzales, N. A., \& Fuligni, A. J. (2019). Emotional coregulation in Mexican-origin parent-adolescent dyads: Associations with adolescent mental health. Journal of youth and adolescence, 48(6), 1116-1130.

Moed, A., Gershoff, E. T., Eisenberg, N., Hofer, C., Losoya, S., Spinrad, T. L., \& Liew, J. (2015). Parent-adolescent conflict as sequences of reciprocal negative emotion: Links with conflict resolution and adolescents' behavior problems. Journal of Youth and Adolescence, 44(8), 1607-1622.

Ozdemir, Y. (2014). Parent-adolescent conflict and depression symptoms of adolescents: Mediator role of self-esteem. Dusunen Adam, 27(3), 211.

Paikoff, R. L., \& Brooks-Gunn, J. (1991). Do parent-child relationships change during puberty? Psychological Bulletin, 110(1), 47-66.

Padilla, J., McHale, S. M., Rovine, M. J., Updegraff, K. A., \& Umaña-Taylor, A. J. (2016). Parentyouth differences in familism values from adolescence into young Adulthood: Developmental course and links with parent-youth conflict. Journal of Youth and Adolescence, 45(12), 2417-2430. 
Phinney, J., Ong, A., \& Madden, T. (2000). Cultural values and intergenerational value discrepancies in immigrant and non-immigrant families. Child Development, 71, 528539

Rognli, E. W., Waraan, L., Czajkowski, N. O., Solbakken, O. A., \& Aalberg, M. (2020). Conflict with parents in adolescent depression: Associations with parental interpersonal problems and depressive symptoms. Child Psychiatry \& Human Development, 1-11.

Rote, W. M., \& Smetana, J. G. (2016). Patterns and predictors of mother-adolescent discrepancies across family constructs. Journal of Youth and Adolescence, 45, 20642079.

Rothbaum, F., \& Trommsdorff, G. (2007). Do roots and wings complement or oppose one another?: The socialization of relatedness and autonomy in cultural context. Guilford Press.

Seiffge-Krenke, I., Overbeek, G., \& Vermulst, A. (2010). Parent-child relationship trajectories during adolescence: Longitudinal associations with romantic outcomes in emerging adulthood. Journal of Adolescence, 33, 159-171.

Semeniuk, Y. Y., Brown, R. L., \& Riesch, S. K. (2016). Analysis of the efficacy of an intervention to improve parent-adolescent problem solving. Western Journal of Nursing Research, 38(7), 790-818.

Skinner, O. D., \& McHale, S. M. (2016). Parent-adolescent conflict in African American families. Journal of Youth and Adolescence, 45(10), 2080-2093.

Smetana, J. G. (2011). Parenting beliefs, parenting, and parent-adolescent communication in African American families. In N.E. Hill, T. L. Mann, \& H. I. Fitzgerald (Eds.), African Americanchildren and mental health: Development and context, Vol. 1 (pp.173-197). Santa Barbara, CA: Praeger.

Smetana, J. G., \& Asquith, P. (1994). Adolescents' and parents' conceptions of parental authority and personal autonomy. Child Development, 65(4), 1147-1162.

Sorkhabi, N., \& Middaugh, E. (2014). How variations in parents' use of confronting and coercive control relate to variations in parent-adolescent conflict, adolescent disclosure, and parental knowledge: Adolescents' perspective. Journal of Child and Family Studies, 23(7), 1227-1241.

Tamm, A., Kasearu, K., Tulviste, T., Trommsdorff, G., \& Saralieva, Z. K. M. (2017). Helping parents with chores or going out with friends: Cultural differences in adolescents' responses to potentially conflicting expectations of parents and peers. Journal of Adolescent Research, 32(4), 456-478.

Tõugu, P., Tulviste, T., Schröder, L., Keller, H., \& De Geer, B. (2011). Socialization of past event talk: Cultural differences in maternal elaborative reminiscing. Cognitive Development, 26(2), 142-154.

Tucker, C. J., McHale, S. M., \& Crouter, A. C. (2003). Conflict resolution: Links with adolescents' family relationships and individual well-being. Journal of Family Issues, 24, 715-736.

Turliuc, M. N., \& Marici, M. (2013). What do Romanian parents and adolescents have conflicts about? Revista de Cercetare s, I Intervent, ie Sociala', 42, 28-49.

Van Aken, M. A. G., Denissen, J. J. A., Branje, S. J. T., Dubas, J. S., \& Goossens, L. (2006). Midlife concerns and short-term personality change in middle adulthood. European Journal of Personality, 20, 497-513.

Wang, M. T., Dishion, T. J., Stormshak, E. A., \& Willett, J. B. (2011). Trajectories of family management practices and early adolescent behavioral outcomes. Developmental Psychology, 47,1324-1341. 
INTERNATIONAL JOURNAL OF ACADEMIC RESEARCH IN BUSINESS AND SOCIAL SCIENCES

Vol. 11, No. 5, 2021, E-ISSN: 2222-6990 @ 2021 HRMARS

Weymouth, B. B., \& Buehler, C. (2016). Adolescent and parental contributions to parentadolescent hostility across early adolescence. Journal of Youth and Adolescence, 45(4), 713-729. 